\title{
Effects of Training in Figures of Speech on EFL Learners' Literary Reading Comprehension Ability
}

\author{
Sam Roodi (Corresponding author) \\ Fanshawe College, Canada \\ Email: ssamigorganroodi@fanshawec.ca \\ Masoud Farahmandfar \\ Allameh Tabataba'i University, Iran
}

Received: 23/06/2020

Accepted: 05/08/2020

Published: 01/09/2020

Volume: 1 Issue: 3

How to cite this paper: Roodi, S., \& Farahmandfar, M. (2020). Effects of Training in Figures of Speech on EFL Learners' Literary Reading Comprehension Ability. Journal of Critical Studies in Language and Literature, 1(3), 1-8

DOI: https://doi.org/10.46809/jcsll.v1i3.22

Copyright (C) 2020 by author(s) and Global Talent Academy Ltd. This work is licensed under the Creative Commons Attribution International License (CC BY 4.0).

http://creativecommons.org/licenses/by/4.0/

\section{(c) ()}

\begin{abstract}
One of the major areas of interest in SLA research is the study of the ways in which expert and non-expert readers respond to L2 texts and the fundamental changes that can be brought about in their L2 reading processes through formal instruction. In line with this research tradition, the present quasi-experimental study investigated the effects of formal training in figures of speech on university EFL learners' appreciation of an unseen literary text, Martin Luther King's "I Have a Dream" in the case of this study. Understanding literature requires knowledge of figures of speech.

An experimental group $(n=29)$ and a control group $(n=26)$ of intermediate $3^{\text {rd }}$ year EFL learners, studying English for a B.A. degree at Kashan University, Iran, participated in the study. The participants were first pretested and matched for their level of proficiency in English and their initial reading comprehension ability. In addition to the normal curriculum content, the experimental group received instruction in figures of speech through a course called "Fonun va Sana'at" (Figures of Speech). The control group did not receive this instruction. Both groups were post-tested on their ability to read a literary passage and to appreciate it.

The results of t-test analysis of the resulting data revealed significant differences between the means of the two groups. The experimental group that had received instruction in figures of speech significantly outperformed the control group. The findings of the study have practical implications for material development, curriculum planning, teaching English through literature, and second language acquisition.
\end{abstract}

Keywords: Literary appreciation, Reading Comprehension, Formal Instruction, Figures of Speech

\section{Introduction}

Enabling second language learners to read texts in their L2 is one of the major aims of many language teaching programs. This is specially the case in EFL settings where learners do not find many opportunities to orally interact with other speakers of the foreign language. This is why EFL teaching programs are basically reading-based in EFL settings like Iran (Atai and Afghari, 2000). 
Because of the undeniable significance of the reading skill in EFL settings, there has been a proliferation of research in this area after the neglect of this skill under the influences of the communicative movement in ELT for some time. One major preoccupation of the research in this area is to find better ways of teaching the reading skill. Another aim is to explore the factors that influence success in reading and the differences that can be found between non-expert and expert readers. Yet another major preoccupation in the area of ESL (standing here for the "Empirical Science of Literature") is the way nonexpert and expert readers respond to literary texts.

Research on literary reading comprehension has not yet fully explored the causes that lead to EFL learners' better understanding of literature through reading. Many learner variables such as socio-cultural, psycholinguistic, and educational variables are apparently active in determining one's proper understanding of literary texts in a second or foreign language.

Of the many possible causes of success or failure in EFL reading in general and in reading literature in EFL in particular, this study focuses on figures of speech. Figurative language imposes great demands on the EFL learner. Moreover, it is one of issues that has not been well researched: "Figurative language, and the ways in which we can increase student awareness of it, has perhaps been given less attention than it deserves" (Lazar, 1996: 46). It is however important to consider that "inclusion of literature in language teaching materials will provide students with the opportunities to experience and use the language more creatively and to develop greater awareness of the language they are learning" (Daskalovska \& Dimova, 2012, p. 1182). Mason and Krashen (2004) have also underlined the efficiency of learning a foreign language in a literary context.

The present study seeks to find answers to the question whether formal training in figures of speech can help students to better understand and appreciate works of literature. More specifically, the present attempt investigates the effects of formal training in figures of speech on university EFL learners' understanding of an unseen literary text, Martin Luther King's 'I Have a Dream".

\section{Review of Literature}

Research on the reading skill has usually attempted to find links between different kinds of learner-related variables and ultimate success in different areas of the reading skills and has only recently tried to empirically test the effects of formal instruction. Nowadays, there are major traditions of research that seek to define and describe the nature of the expertise involved in producing and comprehending written texts. Issues become even more complex when it comes to reading literary texts. According to Bortolussi and Dixon (1996),"over the past decade, numerous formal and informal studies have grappled with the difficult problem of defining or describing the nature of literary expertise" (p. 471).

One of the most significant factors that is expected to positively affect literary appreciation is formal instruction in the use and perception of literary language. Bortolussi and Dixon (1996) provided experimental evidence on the way literary training can affect literary appreciation. They assessed students' reception of a major story from the school of "magic realism" before and after a course in which students received instructions and did some practice on magic realism genre. In this endeavor, Bortolussi and Dixon come to the conclusion that "instruction can lead to fundamental changes in the way in which texts are read and received"'(p.471).

This view has been challenged, however, by people like Nardocchio (1992) whose study of a group of graduate students in Canada and France produced the result that, "Being highly informed about literature ... is not a significant factor when analyzing a specific genre or using a specific methodology" (p. 270).

In spite of these controversial results, readers' experiences and the way they have been taught and trained in reading literature seems to be a very influential factor in the way readers analyze and comprehend literary texts. Culler (1975), for example, writes that those who are not familiar with literature and "the conventions by which fictions are read, would ... be quite baffled if presented with a poem." Culler further argues that "the knowledge of the language" alone may help such people comprehend "phrases and sentences" but it will not necessarily enable them to read literature "as literature" because they do not possess "the complex "literary competence"” which enables others to appreciate literature. This, observes Culler, is because such novice readers have not "internalized the 'grammar' of literature" which would allow them "to convert linguistic sequences into literary structures and meanings" (p. 114).

Brumfit (2000) also believes in "literary competence". He notes that a "true literature syllabus will not be simply the use of literary texts for advanced language purposes, but an attempt to develop or extend literary competence." (p. 27). Brumfit is cognizant of the fact that literary competence is not a concept that can be easily defined (p. 185) because, as many critics have pointed out, one cannot arrive at a final meaning after reading a literary text because readers approach literature with their own particular backgrounds, personal experiences and emotional baggage. As Jacques Derrida held, texts do not possess a "special ontological status" and do not have "one and only one correct interpretation"; texts are rather "undecidable" and can have multiple interpretations and can be "reread and thus interpreted countless times" (Bressler, 2007, p.126).

Stanley Fish (1980) believes that it is wrong to talk about "literary texts". He argues that we should talk about "interpretive communities". As Fish explains, "interpretive community" refers to a group of people who share the same schemata and assumptions about how a text should be read. These communities use the same "interpretive strategies" to understand texts. These interpretive strategies, maintains Fish, affect the actual act of reading. Moreover, different reading communities generate different interpretations of the same text. For example, children in the 21 st century normally read Jonathan Swift's Gulliver's Travels as a children's story, whereas, if you ask expert readers (in this case, a group of 
university professors who specialize in the 18th century literature) to interpret the same story, they would read allegorical meanings into this work. They would read, for instance, the fight between the Lilliputians and Belfuscans as the fight between Protestants and Catholics. The Lilliputians and Belfuscans fight over a religious question: "At which end should the faithful break their eggs?" Our experts would read this episode as a parody of the futile fight between Protestants and Catholics who are at each others' throat for nothing; whereas, our children might just take it as a joke and laugh at it. Dorfman (1996) has provided empirical test of Fish's "interpretive community" by comparing interpretive strategies used by expert and novice readers who responded to short stories from three literary traditions (science fiction, modern British fiction and postmodern fiction) and assessed responses to each by evaluating readers' "understanding, enjoyment, and appreciation of the three story types" (p.453).

The present study compares two groups of readers or "reading communities": a group of university level EFL readers trained in the use and comprehension of figures of speech, on the one hand, and a second group of similar readers not yet familiar with figures of speech, on the other.

\section{Research Methodology}

This study used a quasi-experimental design. Two classes were selected and pretested on language proficiency and reading ability. One group received an instructional treatment on figures of speech. The groups then took test of literary reading comprehension. The data colleted from the groups was finally described and the mean differences between the groups were compared through t-test analyses.

\section{Participants}

A total of 55 undergraduate male and female students took part in this study. This sample included an experimental group $(n=29)$ and a control group $(n=26)$ of intermediate 3rd year EFL learners, studying English at the English Department of Kashan University, Kashan, Iran. The age range of the participants was between 19 and 24. All of them were studying English as a foreign language to obtain a first degree (BA) in English Language and Literature. The experimental and the control groups were the students of two intact classes selected for their relatively equal levels of English proficiency and reading ability as well as for the practical considerations of the research. The participants had been admitted through a nation-wide university entrance examination (called Konkur) and were taking their 16-hour to 20-hour courses per week. Before the experimental class underwent formal training in figures of speech, tests were given to both classes to determine possible significant differences in their English proficiency in general and in reading comprehension ability in particular. The participants were kept in the dark regarding the real purpose of the tests and took them as natural parts of their assessment.

\section{Instruments}

The instruments used for the collection of the research data included an English proficiency test, a measure of reading comprehension, instructional materials on figures of speech presented by the teacher, and a final test of literary reading. The proficiency test was an unseen sample TOEFL test including 80 items on grammar and written expression, vocabulary, and reading comprehension. The reading comprehension test was the reading section of another unseen sample TOEFL test considered along with the participants' records on reading comprehension courses. The final test, which was designed to measure the learners literary reading ability was a 25-item multiple-choice test on the transcribed text of Martin Luther King's "I have a Dream" which tested students understanding of the figures of speech used in the text. This test was developed by the researchers. The test was shown to be reliable based on the statistical analysis of the data. (Cronbach's Alpha: 0.76).

The reading materials were selected by the instructor to make basic figures of speech tangible for the learners. The teaching began by considering how figures of speech were being used by the people in the street. Learners then examined texts that they might read or speech that they might hear in everyday life which had poetic qualities and could be considered "poetic". Learners were taught that figurative language was not necessarily a specialized language and that it was not confined to poetry and literature. They were helped to understand the significance of formal training in figurative devices by examining the language of the people, often loaded with figures. Then, they focused on a selection of literary texts to see how figurative devices were employed by writers of literary texts. A knowledge of the figures of speech was presented to help students to recognize figures in context and appreciate their significance for the comprehension and appreciation of literary texts.

\section{Procedures}

Two intact groups attending undergraduate courses in English Literature at the English department of Kashan University, Iran, who were believed to be similar in terms of general English proficiency and reading ability levels were selected for participation in the study. Students in each of these groups were asked to take tests of proficiency and reading ability as parts of their course requirements so we could test any significant differences between the groups in terms of English language 
abilities. One group was trained in figures of speech in addition to taking the normal curriculum content. Both classes were then asked to read and respond to a text embellished with figures of speech, Martin Luther King's "I have a Dream".

Responses were assessed by different questions that examined our readers' comprehension and literary appreciation. Our hypothesis was that readers in each group would display different responses. It was assumed that sophisticated readers would show deeper understanding of our literary text. The collected data were summarized, analyzed, and discussed in the light of the related literature.

\section{Analyses and Results}

The participants in this study were intermediate EFL learners and their proficiency level was measured using an 80-item proficiency test. Table 1 shows the descriptive statistics on the proficiency level.

Table 1: Descriptive Statistics for EFL proficiency

\begin{tabular}{|l|r|r|r|r|r||}
\hline \multicolumn{1}{|c|}{ Group } & N & Sum & Mean & Std. Deviation & Variance \\
\hline Experimental Group 2 with Instruction & 29 & 791.00 & 27.2759 & 4.7124 & 22.207 \\
\hline Control Group 1 No Instruction & 26 & 654.00 & 25.1538 & 5.5763 & 31.095 \\
\hline
\end{tabular}

As table 1 shows the experimental group had a slightly higher mean proficiency score. However, t-test analysis showed that this minor difference was not significant.

Table 2: Independent Samples t-test Statistics for Mean differences in EFL proficiency

\begin{tabular}{|r|r|r|r|r|r|}
\hline & \multicolumn{1}{c|}{$\mathbf{t}$} & \multicolumn{1}{c|}{ df } & Sig. (2-tailed) & Mean Difference & Std. Error Difference \\
\hline & & & & & \\
\hline $\begin{array}{r}\text { Equal variances } \\
\text { assumed }\end{array}$ & -1.529 & 53 & .132 & -2.1220 & 1.3877 \\
\hline $\begin{array}{r}\text { Equal variances } \\
\text { not assumed }\end{array}$ & -1.515 & 49.240 & .136 & -2.1220 & 1.4006 \\
\hline
\end{tabular}

As the t-test results show, the experimental group and the control group were not significantly different in terms of EFL proficiency level. The participants' initial reading ability level did not show any significant differences either.

Table 3: Descriptive Statistics for beginning reading proficiency

\begin{tabular}{|r|r|r|r|r|r|r|}
\hline Group & Nange & Sum & Mean & SD & Variance \\
\hline Experimental Group 2 with Instruction & 29 & 25.00 & 689.00 & 23.7586 & 5.8898 & 34.690 \\
\hline Control Group 1 No Instruction & 26 & 27.00 & 511.00 & 19.6538 & 7.0764 & 50.075 \\
\hline
\end{tabular}

Once again, t-test results showed that the experimental group and the control group were not significantly different in terms of reading ability.

Table 4: Independent Samples t-test Statistics for Mean differences in beginning reading ability

\begin{tabular}{|r|r|r|r|r|r||}
\hline & $\mathbf{t}$ & $\mathbf{d f}$ & Sig. (2-tailed) & Mean Difference & Std. Error Difference \\
\hline & & & & \\
\hline $\begin{array}{r}\text { Equal variances } \\
\text { assumed }\end{array}$ & -2.347 & 53 & .123 & -4.1048 & 1.7492 \\
\hline $\begin{array}{r}\text { Equal variances not } \\
\text { assumed }\end{array}$ & -2.323 & 48.867 & .124 & -4.1048 & 1.7670 \\
\hline
\end{tabular}

A posttest was given to both groups of students that measured their ability in understanding a literary text embellished with figures of speech. Statistics showed great mean differences between the performances of the groups. 
Table 5: Descriptive Statistics for literary reading ability

\begin{tabular}{|r|r|r|r|r|r|r|r|r|r|}
\hline Group & $\mathbf{N}$ & Range & Minimum & Maximum & Sum & Mean & Std. Deviation & Variance & \\
\hline $\begin{array}{r}\text { Literary Reading } \\
\text { comprehension Ability } \\
\text { G2 }\end{array}$ & 29 & 10.00 & 14.00 & 24.00 & 569.00 & 19.6207 & 2.8587 & 8.172 & \\
\hline $\begin{array}{r}\text { Literary Reading } \\
\text { Comprehension } \\
\text { Ability G1 }\end{array}$ & 26 & 13.00 & 7.00 & 20.00 & 395.00 & 15.1923 & 3.4873 & 12.162 & \\
\hline
\end{tabular}

Table 6: Independent Samples t-test Statistics for Mean differences in literary reading ability

\begin{tabular}{|c|c|c|c|c|c|c|c|}
\hline & $\mathbf{t}$ & $\mathrm{df}$ & $\begin{array}{r}\text { Sig. }(2- \\
\text { tailed })\end{array}$ & $\begin{array}{r}\text { Mean } \\
\text { Difference } \\
\end{array}$ & $\begin{array}{l}\text { Std. Error } \\
\text { Difference }\end{array}$ & $\begin{array}{r}95 \% \text { Confidence Interval } \\
\text { of the Difference }\end{array}$ & \\
\hline & & & & & & Lower & Upper \\
\hline $\begin{array}{r}\text { Equal } \\
\text { variances } \\
\text { assumed }\end{array}$ & 5.171 & 53 & .000 & -4.4284 & .8564 & -6.1461 & 2.7107 \\
\hline $\begin{array}{r}\text { Equal } \\
\text { variances } \\
\text { not } \\
\text { assumed }\end{array}$ & 5.115 & 48.485 & .000 & -4.4284 & .8658 & -6.1687 & 2.688 \\
\hline
\end{tabular}

The analysis of the data collected in this study showed that the EFL learners who received instruction on the use and comprehension of figures of speech significantly outperformed those who did not, suggesting that formal instruction in figures of speech can significantly improve learners understanding of literary texts.

\section{Discussion and Conclusion}

The present study showed that formal instruction in figures of speech can significantly improve EFL learners approach to the perception of literary texts. Before EFL learners begin to appreciate English literature or learn English through literature, they need to be trained in the use of figures of speech.

Unlike the old-fashioned definition, figurative language cannot be considered as "any deviation, either in thought or expression, from the ordinary and simple method of speaking," but a kind of fresh and artistic usage which makes it different from common usage. Knowledge of the figures presented in this study helped students to recognize figures in context and eventually use their knowledge to understand literature better and make their reading more enjoyable.

\section{References}

Atai, M. R., \& Afghari, A. (2000). The Effect of Explicit Instruction of Discourse Structure on EAP Learners' Reading Comprehension Performance. Iranian Journal of Applied Linguistics 4 (2), 19-35.

Bortolussi, M., \& Dixon, P. (1996). The Effects of Formal Training on Literary Reception. Poetics, 23, 471-487.

Bressler, C. E. (2007). Literary Criticism: An Introduction to Theory and Practice. 4th ed. New Jersey: Pearson Prentice Hall.

Brumfit, C. (2000). Reading Skills and the Study of Literature in a Foreign Language. Literature and Language Teaching. Eds. C.J. Brumfit, and R. A. Carter. Oxford: Oxford University Press. 184- 190.

Culler, J. (1975). Structuralist Poetics. London: Routledge \& Kegan Paul.

Daskalovska, N., \& Dimova, V. (2012.) Why Should Literature Be Used in the Language Classroom? Procedia: Social and Behavioral Sciences, 46, 1182-1186.

Dorfman, M. H. (1996). Evaluating the Interpretive Community: Evidence from Expert and Novice Readers. Poetics, 23, 453-470.

Fish, S. (1980). Is There aText in This Class? The Authority of Interpretive Communities. Cambridge, MA: Harvard UP.

Lazar, G. (1996). Using Figurative Language to Expand Students' Vocabulary. English Language Teaching Journal , 5 (1): 43-51.

Mason, B., \& Krashen, S. (2004). Is Form-Focused Vocabulary Instruction Worthwhile? Regional Language Centre Journal (RELC), 35(2): 179-185. 
Nardocchio, E. (1992). Reader Response to Literature: The Empirical Dimension. New York: Mouton de Gruyter.

\section{Appendix One: The Test of Literary Reading}

Read the following parts from Martin Luther King's "I Have a Dream” and answer the questions following each part.

\section{Part One}

I am happy to join with you today in what will go down in history as the greatest demonstration for freedom in the history of the Nation. Five score years ago, a great American, in whose symbolic shadow we stand today signed the Emancipation Proclamation. This momentous decree came as a great beacon of light and hope to millions of Negro slaves who had been seared in the flames of withering injustice. It came as a joyous daybreak to end the long night of their captivity. But one hundred years later, the Negro is still not free. One hundred years later, the life of the Negro is still sadly crippled by the manacles of segregation and the chains of discrimination. One hundred years later, the Negro lives on a lonely island of poverty in the midst of a vast ocean of material prosperity. One hundred years later, the Negro is still languishing in the corners of American society and finds himself an exile in his own land. So we have come here today to dramatize a shameful condition. In a sense, we have come to our nation's capital to cash a check. When the architects of our republic wrote the magnificent words of the Constitution and the declaration of Independence, they were signing a promissory note to which every American was to fall heir. This note was a promise that all men, yes, black men as well as white men, would be guaranteed the unalienable rights of life, liberty, and the pursuit of happiness.

\section{The great American whom the speaker mentions is probably...........}

A slave

A politician

Standing next to the speaker to provide shadow

One of the greatest slave traders in the USA

2. The momentous decree has been referred to as

A fire burning the Negro

A sign of injustice

The flame of slavery

The source of happiness

3. The chains and manacles that the speaker is talking about.......

Are the things used for torturing Negro prisoners

Are used for segregating people

Indicate the hardship of segregation and discrimination

Indicates what the Negro used to fight discrimination

\section{Every American, black as well as white,}

Was supposed to be entitled to the rights mentioned in the constitution

Was expecting to be given a promissory note

Was promising to sign the first words of the constitution

Was supposed to declare independence as signed by the architects

\section{According to the speaker, where does the Negro live 100 years after the proclamation?}

In one of the islands of the USA

In a vast ocean near the USA

In terrible conditions all over the USA

With material prosperity everywhere

\section{Part Two}

This is no time to engage in the luxury of cooling off or to take the tranquillising drug of gradualism. Now is the time to make real the promises of democracy. Now is the time to rise from the dark and desolate valley of segregation to the sunlit path of racial justice. Now is the time to lift our nation from the quicksands of racial injustice to the solid rock of brotherhood. Now is the time to make justice a reality for all of God's children. It would be fatal for the nation to overlook the urgency of the moment. This sweltering summer of the Negro's legitimate discontent will not pass until there is an invigorating autumn of freedom and equality. Nineteen sixty-three is not an end, but a beginning. Those who hope that the Negro needed to blow off steam and will now be content will have a rude awakening if the nation returns to business as 
usual. There will be neither rest nor tranquility in America until the Negro is granted his citizenship rights. The whirlwinds of revolt will continue to shake the foundations of our nation until the bright day of justice emerges. But there is something that I must say to my people who stand on the warm threshold, which leads into the palace of justice. In the process of gaining our rightful place we must not be guilty of wrongful deeds. Let us not seek to satisfy our thirst for freedom by drinking from the cup of bitterness and hatred. We must forever conduct our struggle on the high plane of dignity and discipline. We must not allow our creative protest to degenerate into physical violence. Again and again we must rise to the majestic heights of meeting physical force with soul force.

6. By mentioning "the tranquilizing drug of gradualism", the speaker means that........

the Negro should not use medicine that might slow down their work.

drug addiction will gradually cool the Negro people.

there is no use in waiting for gradual political changes.

Grdadual activities and tranquility can bring pleasure

\section{The "valley of segregation" is}

a place

similie

metaphor

ironic

\section{The speaker is inviting people to move towards.....}

a desolate valley

racial justice

segragation

a sunlit place

\section{Summer and autumn in the above text are associated with....}

Demonstration and injustice

Demonstration and freedom

Freedom and equality

Equality and injustice

10. Based on the text, the thirst for freedom can be best quenched by.....

consuming more than a single cup of water

drinking from the cup of hatred and bitterness

avoiding the development of hatred

not trying to satisfy it at all

\section{Part Three}

This is our hope. This is the faith that I go back to the South with. With this faith we will be able to hew out of the mountain of despair a stone of hope. With this faith we will be able to transform the jangling discords of our nation into a beautiful symphony of brotherhood. With this faith we will be able to work together, to pray together, to struggle together, to go to jail together, to stand up for freedom together, knowing that we will be free one day. This will be the day when all of God's children will be able to sing with a new meaning.

11. The speaker goes back to the South with the faith that..... gradualism is good at the present time equality can be achieved at last we are all God's children and equal we can play good music in a symphony

12. At the time of this speech, the American nation ........ was united all the time was playing bad music could not be harmonious and cooperative transformed its discords to a symphony

13. Freedom and equality have been described by all but one of the phrases below: Symphony of Brotherhood 
Singing with new meanings

Doing everything together

Helping in digging stones

14. Stand up for freedom means........

accept freedom

reject freedom

show discontent in the absence of freedom

use violence to achieve freedom

15. The faith makes the Negro hopeful that they can one day.........

go to jail together

work together

struggle for freedom together

live freely in America

\section{Based on the above passages, Mark A for correct statements and B for false statements.}

16. People are listening to this address because they want to sign the emancipation proclamation.

17. The great American who signed the proclamation intended to burn the Negroes in the fire of the proclamation.

18. The person who signed the proclamation is dead at the time of this speech.

19. The Negro has been sent to another country as an exile.

20. The people listening to this talk are in front of a bank trying to cash a check

21. It was wrong for the architects to write the constitution because it should have been done by the politicians.

22. The promises of US democracy had not been realized yet at the time of this speech.

23. Injustice is shaky, equality strong and solid.

24. It is lawful for the Negro to protest against the disrespect of their freedom.

25. The speaker asks people to hew out stones from the mountains in America.

\section{Appendix Two: The Description of the aims of the instructional treatment}

This course is an introduction to figurative language for EFL students. The approach used is intellectually demanding and might not be suitable for less motivated students or students below mid-intermediate level who might not be equipped with the necessary meta-language for discussion. The course is devoted to learning figurative devices and to reading representative poetic and prose texts in order to enable students to recognize and use figurative language in context. As Paul de Man observes, tropes are not a "derived, marginal, or aberrant form of language but the linguistic paradigm par excellence." One of the fallacies about figurative texts is that their language is artificially decorative, something to make the texts more literary and dramatic. Language is a colorful tapestry, not a plain weave. Nietzsche was right when he commented that language is inherently figurative and that its meaning cannot be separated from its figures. Based on this assumption, firstly, this course explores the function of figures in everyday speech. We begin the course by considering how figures are being used by the people in the street. We will examine texts that students might read or speech that they might hear in everyday life which have poetic qualities and could be considered "poetic". Then, this course focuses on a selection of literary texts to see how figurative devices are employed by writers of literary texts and how they can help us appreciate such texts. We will try to grasp the fact that, unlike the old-fashioned definition, figurative language cannot be considered as any deviation, either in thought or expression, from the ordinary and simple method of speaking, but a kind of fresh and artistic usage which makes it different from common usage. Having been made aware of the various figurative devices such as metaphor and its related terms (simile, personification, apostrophe, allegory, fable, symbol, metonymy, ...), irony, ambiguity, pun and rhetorical schemes (amplification, parallelism, palindrome, chiasmus, ...), it is hoped that students may make a conscious effort to use figures in writing and speech when they see that they suit their purpose and be able to recognize them in contexts of literary productions. This course is conducted primarily by students except for some introductory lectures in each session. Students are expected to take part in class discussions and submit one major paper by the end of the term. Apart from this text-book, some additional readings may also be introduced and announced on a week-by-week basis. In addition to keeping up with the readings and the writing assignments, students may be asked to contribute their own insights to the collective knowledge of the class. 